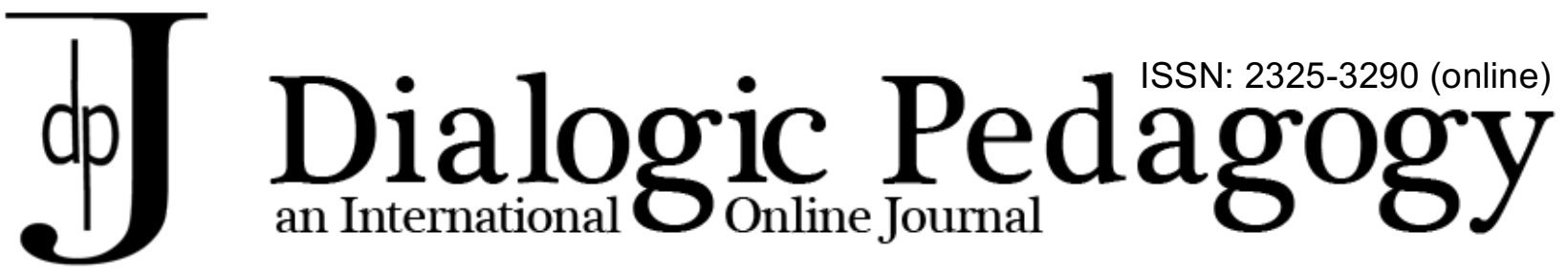

\title{
M. M. Bakhtin as a University Professor ${ }^{1}$
}

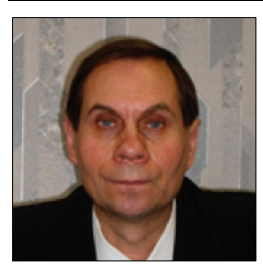

Nikolai L. Vasiliev

Mordovia State University, Russia

\begin{abstract}
This article presents M. M. Bakhtin as a University professor through his own views of on the nature of university teaching: lecturing, seminars and colloquia, engaging students in debates and reflexive analysis of literary texts, "scientific thinking", and working with bibliography. As a Chair of Russian and Foreign Literature department of the Mordovian National Pedagogical Institute (later the Mordovia State University), for a quarter of a century, Bakhtin was promoting teaching approaches that would support students' informed, independent, analytical and reflexive learning. According to the minutes from different department meetings at his university, over the years, Bakhtin struggled to define and improve his own guidance and teaching in the Literature studies and the overall work of his department. His three pedagogical goals for a literary lecture were: 1) Communication of certain information on a given topic establishing the level of students' familiarity with the topic; 2) Fostering students' scientific thinking; and 3) Fostering students' aesthetic perception and taste. Some of his former students emphasized his erudition, pedagogic skill, and ability to stimulate his students' imagination and reflective thinking.
\end{abstract}

Nikolai L. Vasiliev is a professor of philology at Mordovia State University, Russia. He is interested in the studies of the lives and scholarship of Bakhtin, Medvedev, and Voloshinov; theory of language; history of Russian literary languag; lingopoetry of Russian writers; writers' lexica; history of Russian literature; history of Soviet/Russian philology of the first half of the XX century; and study of local lore.

$\cos \cos 80$

In their memoirs about Bakhtin as a professor of the Mordovian Pedagogical Institute (1946-1961), his former students emphasized his erudition, pedagogic skill, and ability to stimulate his students' imagination and reflective thinking.

L. R. Vdovina, a literary critic who studied in the Mordovian Pedagogical Institute in the second half of 1940s, writes the following about Bakhtin: "He was a very lively, active, and energetic man. The expression of his face was amazing... It was constantly changing. It could fluctuate from ironical to sternly judgmental, from trusting and intimate to furious, from thoughtful to grumpy... truly, an unlimited gamut of expressions. [...] Bakhtin spoke in a loud, clear voice, and with a lot of emotion, as if he was performing on stage... No matter what he was talking about [...], he always had his own opinion about everything. [...] He

\footnotetext{
${ }^{1}$ A fragment from the 2014 monograph "Mikhail Mikhailovich Bakhtin and the phenomenon of 'the Bakhtin circle': In search of lost time. Reconstructions and deconstructions. Squaring the circle" ("Михаил Михайлович Бахтин и феномен "Круга Бахтина": В поисках утраченного времени. Реконструкции и деконструкции. Квадратура круга"), Moscow, Librokom, pp. 22-29. Translated and published here with the agreement of the author. Translation from Russian by Yury Almetev.
} 
could easily recite whole passages in German, English, or Greek. He would give us examples of such subtle critique of literary texts, that they would become engraved in our memory. [...] Sometimes it felt as though in his lectures he was engaged in a dialogue with an invisible opponent. Once he said: 'Every book argues with somebody.' That meant that we were not to trust implicitly everything written in books... That was, probably, the reason, why he once said that literature textbooks were 'evil... but a necessary evil.' In his numerous students Bakhtin tried to foster the ability to think, to reflectively analyze what one read, to have a diverging opinion... He advised us to read slowly, taking our time" (Vdovina, 1991).

Y. F. Basikhin, Bakhtin's post-graduate advisee, wrote this in his memoir: “...It was in 1948. [...] We were first-year students at the time and we used to spend many autumn evenings in the university library... reading, arguing, and talking about professor Bakhtin's lectures. For the first-year students he was giving a course on Ancient Greek literature. At first, it was difficult for us, the newbies, to understand Bakhtin's lectures. We were totally unfamiliar with Ancient Greek literature back then - it was so alien to us. But Mikhail Mikhailovich made it close to us. As if by magic, the new, enchanting literary horizons now loomed before us. Homer's heroes suddenly became close and familiar to us..." "Mikhail Mikhailovich's lectures were full of passion and enthusiasm... It was unforgettable when he recited 'The lliad' in Ancient Greek for us..." (Basikhin, 1968, pp. 243-244). Other students of M. M. Bakhtin write about their mentor with similar gratitude.

In this context, it would be interesting to consider the views of Bakhtin himself on the nature of university lectures, on students' independent studies, and on the principles of organization of the educational process that he used as the Chair of Russian and Foreign Literature department of the Mordovian National Pedagogical Institute (later the Mordovia State University), where the scholar worked for a quarter of a century².

Bakhtin repeatedly addressed the issues of teaching methodology applied in higher education both among his colleagues and in press. For instance, on October 30, 1954, the question of "Students' selfeducation" was being discussed at the department meeting. During the discussion, Bakhtin pointed out the following: "More attention should be paid to bibliography. What students know about bibliography is insufficient - therefore, they should be provided with bibliographic guidelines for each course topic. Every student, by his graduation from college, should have solid bibliographic knowledge for each studied course". It must be mentioned that not all of his colleagues met Bakhtin's suggestion with approval - for example, Professor M. A. Patrakeev retorted that "students should be familiar only with the most essential bibliography" ${ }^{3}$.

On July 2, 1956, in his report at the department meeting, Bakhtin stated that he had delivered a few lectures of supportive nature for first-year students, namely "1. Methods of independent work with books; 2 . Methods of note-taking at university lectures. And a lecture on teaching the theory of literature in secondary school, which was given for school teachers."

On January 14, 1957, Bakhtin shared the following thoughts with his colleagues: "We must fight against routine in university education. There should be fewer lectures and more practical classes. The number of lectures must be reduced. If some topics are explained well in the textbook, they should just be referred to, but it is the material that is not explained well, that needs to be taught. Students tend to rely on lectures, but we need to encourage their self-study. There should be more debates, discussions,

\footnotetext{
${ }^{2}$ Even after his retirement in September 1961, Bakhtin continued working as an academic advisor for post-graduate students of the Russian and Foreign Literature Department of the Mordovia State University, participated in its research, and advised his colleagues.

${ }^{3}$ Central State Archive of the Republic of Mordovia, P-546, op-1, 343, 5.

${ }^{4}$ Central State Archive of the Republic of Mordovia, P-546, 56.
} 


\section{M. Bakhtin as a University Professor}

Nikolai L. Vasiliev

conferences. [...] It should also be noted that students have poor knowledge of aesthetics and arts. We should speak about music and painting in our lectures. Colloquiums are necessary, even though they often get rejected"5.

On January 6, 1958, the department discussed the methodological principles of seminars and practical classes. Bakhtin shared the following ideas: "The more variety of methods we offer the better but, most importantly, they should be practically useful. Practical classes have only educational goals. Special seminars have scientific research goals. We should strive to make special seminars more research oriented. Practical classes can use various methods - reports, methodological discussions, and especially the analysis of texts. Too little attention is paid to bibliography. It is paramount to select a topic for a special seminar and it should be as narrow as possible. We must also pose debatable questions to students"; "... and every student should have a diary or a notebook to write down his thoughts and opinions"; "a report must be done in writing, as it represents scientific research, but it is not necessary to simply read the text out loud"; "students must be taught how to read monographs"6.

On March 3, 1958, after hearing the reports of his colleagues about their work in the previous semester, Bakhtin said: 'When I was observing students' work at seminars and exams, I could see that many students simply summarized literary works, instead of analyzing them. We need to pay more attention to artistic forms. Our students are totally lacking their own approach, aesthetic judgement, they know very little by heart, and cannot substantiate their point of view. We must deal with these shortcomings"7.

In the same year, Bakhtin shared his views on the work with scientific literature with his students and colleagues. Since this source is virtually unknown outside of Mordovian scholarly circles, we will quote its most relevant parts:

When you start studying a scholarly book, you should never expect to understand it easily and quickly. Science is always complex and it can take time to understand a treatise or even a textbook: they require a significant concentration of the mind and hard work.

When you study any book, it is important not only to learn all the facts and scientific concepts it contains, but also the methods that were used to find, establish, and prove those facts. You must try to master the very logic of science.

When you study something on your own, you should not forget the practical side. You should always find connections between theoretical concepts and real life - try to find possible practical applications of these concepts. Surely, this must not be done superficially: some theoretical concepts cannot have direct applications. [...] But the general direction towards practice should be a necessary condition for understanding any scientific book. A scientist, an engineer, or a professor needs such an amount of scientific information for their work, as cannot be contained in one person's memory. That is why it is very important to know where and how certain information can be found. For this reason, you need to thoroughly investigate the bibliography of your field of knowledge, acquire the skills of working with various kinds of reference books, and the overall skills of working with books - so you can quickly find what you need in them. [...]

Referential information is located outside the book's main text: before it, after it, and at the bottom of the page, in footnotes. It usually includes the following elements: the

\footnotetext{
${ }^{5}$ Central State Archive of the Republic of Mordovia, P-546, 74.

${ }^{6}$ Central State Archive of the Republic of Mordovia, P-2542, 24, 9.

${ }^{7}$ Central State Archive of the Republic of Mordovia, P-2542, 12.
} 
front page, prefaces, afterword, and footnotes [...]. Other such elements include commentaries (usually placed in the end of the book), tables of contents, various kinds of references, maps, diagrams, and charts.

The differences in the constituent parts of a book depend on its specialty. However, one should always start working with any scholarly treatise with a preliminary perusal of its references, so that later the whole text can be systematically used from its first page to its very end. The work with referential data teaches students to be accurate and rigorous in their research and it fosters their appreciation of bibliography. Reading a book without a thorough use of its references is unproductive and scientifically deficient" (Bakhtin, 1958, pp. 17-19).

On July 15, 1959, speaking about the current goals of the department, Bakhtin stated the following: "We must pay serious attention to the special courses. Our students have poor knowledge of many scientific disciplines, such as textology, stylistics, and source study. There is an urgent need to address this issue. Our students have poor knowledge of bibliography. We need to creatively rework our courses' syllabi instead of simply rewriting them ${ }^{8}$.

On August 31, 1960, Bakhtin proposed to offer a new course for $5^{\text {th }}$-year students, called "Lectures on Bibliography of Russian Literature." On October 20 of the same year he recommended all the department professors to conduct tutorials with first-year students on "Methods of note-taking" (both proposals were met with approval).

On December 27, 1960, the question of lecturing methodology was discussed at the departmental meeting. The main presenter, and probably the organizer of the discussion, was Bakhtin. Here is an excerpt of the meeting's hours concerning his presentation:

In his speech M. M. Bakhtin said that he would just pose a few questions about the methods of lecturing at a university. A Literature lecture should pursue three main goals:

1. Communication of certain information on a given topic; establishing the level of students' familiarity with the topic;

2. Fostering students' scientific thinking;

3. Fostering students' aesthetic perception and taste.

Goal 1. All kinds of knowledge can be divided into two main groups:

a. Essential knowledge, proven and established by science; and

b. Debatable knowledge.

In their lectures, professors must deliver both essential and debatable knowledge, even though there is a notion that a lecturer should only deliver essential knowledge and avoid any debatable questions.

Students' scientific thinking is fostered through their learning about diverse opinions and scientific debates. Nevertheless, lecturers must underline the difference between these two types of knowledge. The lecturer should also emphasize his own point of view in his lecture. Special attention should be given to those questions that belong to the specific domain of the professor's expertise. Then he can share a lot of new information with students.

The curriculum does not provide much time for lectures - that is why it is impossible to deliver all the materials. Therefore, professors should deliver such information in their

${ }^{8}$ Central State Archive of the Republic of Mordovia, P-2542, op.1, p. 24, 34. 
lectures that is not contained in the textbook. Students are usually quick to notice when a lecturer is simply reduplicating the textbook's material. They lose any interest towards such lectures and engage in all sorts of extraneous activities in the classroom. Many textbooks are outdated and need to be brought up-to-date with recent scientific achievements.

Lecturers should avoid delivering truisms (e.g., $2 \times 2=4$ ) or sharing details of their autobiography. You can find these in secondary school textbooks. However, if they have learned something new about a writer from his autobiography, they should share it. Students need to know that. Autobiographical data is relevant when it can be used in analysis, when a certain point needs to be clarified ${ }^{9}$.

About literary analysis. University lecturers often give analysis in its most simplified form - similar to how it is done at secondary school. Some lecturers adhere to the widespread notion that students must only be given that information in lectures that they can use later in schools. Such materials can be found in any school textbook. On the contrary, lecturers should provide a deeper treatment of a scholarly topic. They should give examples of scientific analysis (instead of banal truths).

Interpretation of a literary work is limited by subjectivity. Each literary work has its sources. They should be discussed in lectures. Lecturers should know the history of the literary text.

The question of genre should be treated with the utmost attention. Students often have no idea of the genre of a given literary work. The analysis of a literary text should always start with defining its genre. A lecturer must specifically emphasize the analysis of the artistic form in their lecture - they should always clarify and underline their own opinion (about any book).

Goal 2. How can we teach scientific thinking? Lecturers must showcase it in their own work, rather than talk about it. We must be engaged in reflective thinking in the classroom, in front of our students (doubting, assessing the validity of arguments, etc.) A lecture must become the starting point for an ongoing process of thinking.

Goal 3. Cultivating students' aesthetic perception. Literature study is a science that explores aesthetic phenomena. Literature is one of the arts (another example is music). We must foster students' aesthetic perception and taste. The majority of our graduates have a very poor understanding of literature. In our lectures we must reveal the artistic nature of literature - for instance, by comparing literature and music ${ }^{10}$.

The presentation triggered a discussion, during which Bakhtin's colleagues both expanded his ideas and contested them. A. M. Kukanov noted that the Department Chair "did not touch upon the historic method, which is essential in the teaching of literature. For example, [Russian famous writers and poets] Pushkin, Nekrasov, Lomonosov, and Gorky all have "narodnost" in their works. But how are they different in their "narodnost"? Without answering such questions, the study of literature would be incorrect. Besides "narodnost", M. M. Bakhtin did not touch upon the literary process in his discussion of lecturing methods. To what extent do we really need classicism? [...] The analysis of a literary work should begin with defining its idea, its theme, and not its genre" (Kukanova, 1997).

V. M. Zabavina said that "every lecturer should pay more attention to defining the time period, in which a certain author's worldview was formed". She supported A. M. Kukanov's idea to briefly summarize authors' philosophical views. In conclusion, Bakhtin said the following: "The discussion was productive. Ideological upbringing of students can be partly achieved through providing them with scholarly materials.

\footnotetext{
${ }^{9}$ In this context, "autobiography" can be understood as "biography of a writer".

${ }^{10}$ Central State Archive of the Republic of Mordovia, P-2542, p. 10, 12. Some fragments of this speech by Bakhtin are cited from the book by S.S.Konkin, \& L.S.Konkina. Mikhail Bakhtin: Stranitsy zhizny I tvorchestva. 1993, Saransk.
} 
We must give them as much academic knowledge as possible. We need the historic method and we need to study the time period, but we do not have the opportunity to provide a detailed depiction of the historic period. For this, we need to refer students to textbooks. A lecture is one of the "links" that constitute the course. Each and every lecture must be connected to the previous one and usher in the following one. Improvisation is a component of a lecture - it comes as a result of good knowledge of your subject matter, your field of study. Many things can be touched upon in a lecture. But we must be careful in selecting the lecture material." ${ }^{11}$

On February 9, 1961, Bakhtin shared his opinion on synoptic lectures for students preparing for graduation examinations: "We must begin giving synoptic lectures on literature. We cannot reduce the number of synoptic lectures. Students have to know the materials of the discussion on [Alexander Pushkin's] "Eugene Onegin" and other discussions. We should inform students about these materials. Every professor should include in his lectures bibliographic questions and questions on the theory of literature. Students should be introduced to all aspects of the literary process. Textology questions should also be discussed with students. Students, probably, do not even know that there exist three texts of [Yury Lermontov's famous poem] "The Demon." Without that, a work of literature cannot be analyzed." "The questions for State graduation examinations must be revised. Every professor must carefully formulate questions for his course. The questions should include a variety of aspects - the writers' literary careers, the nature of the literary process, problem questions, and questions concerning specific literary works. Questions on the theory of literature should also be included. ${ }^{12,}$

Bakhtin's reflections on the methods of university instruction, based on many years of his teaching experience (Vitebsk, Kostanay, Saransk), seem to be still relevant today. In a sense, the lasting legacy of the famous scholar not only includes his scholarly work but also his thoughts on teaching methodology.

\section{References}

Bakhtin, M.M. (1958). Nekotoriye zamechaniya. Mordov. Universitet, November 18. Reprinted in M.M.

Bakhtin: Esteticheskoye Naslediye I Sovremennost'. Mezhvuzovskiy sbornik nauchnyh trudov.

Saransk, 1992, Chast' 1, str. 17-19.

Basikhin, Y.F. (1968). O Mikhaile Mikhailoviche Bakhtine. Rodnye Prostory, Saransk, pp. 203-204.

Central State Archive of the Republic of Mordovia (Tsentral'niy Gosudarstvenniy Arkhiv Respubliki Mordovia).

Konkin, S.S., \& Konkina, L.S. (1993). Mikhail Bakhtin: Stranitsy zhizny I tvorchestva. Saransk.

Kukanova, N.G. (1997). Bakhtiny v nashey zhizni. Strannik, Saransk, 1, pp. 138-146.

Vasilyev, N.L. (2000). M.M.Bakhtin kak vuzovskiy prepodavatel'. Dialog. Karnaval. Khronotop, 1, pp. 45-

52.

Vdovina, L. (1991). "Zamuchen tyazholoy nevoley”. Slovo o Bakhtine. Sovetskaya Mordovia, Jan. 23.

\footnotetext{
${ }^{11}$ Central State Archive of the Republic of Mordovia, P-2542, op. 1, p. 138, 12.

${ }^{12}$ Central State Archive of the Republic of Mordovia, ibid., p. 14.
} 


\section{(cc) EY}

New articles in this journal are licensed under a Creative Commons Attribution 4.0 United States License.

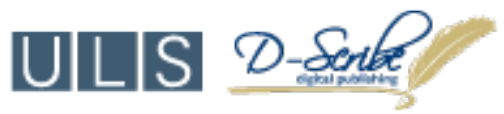

This journal is published by the University Library System, University of Pittsburgh as part of its D-Scribe Digital Publishing Program and is cosponsored by the University of Pittsburgh Press. 